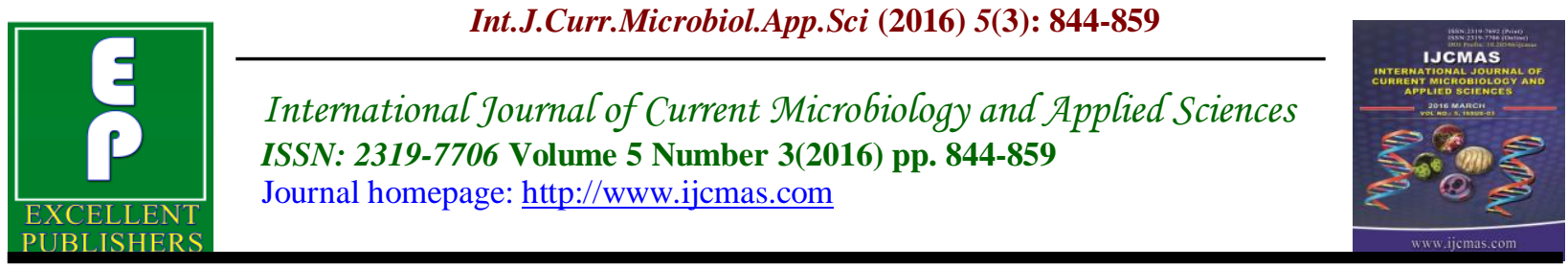

Original Research Article

http://dx.doi.org/10.20546/ijcmas.2016.503.098

\title{
Farmers' Perceptions of Production Constraints and Preferences in Cassava Grown in Semi-Arid Areas of Kenya
}

\author{
Joseph Kamau ${ }^{1}$, Rob Melis ${ }^{2}$, Mark Laing², Paul Shanahan², \\ Jon Derera ${ }^{2}$, Kahiu Ngugi ${ }^{3}$ and Yusuf Migwa ${ }^{1}$ \\ ${ }^{1}$ KALRO-Katumani, Kenya \\ ${ }^{2}$ University of KwazuluNatal, South Africa \\ ${ }^{3}$ University of Nairobi \\ *Corresponding author
}

\begin{abstract}
A B S T R A C T
Keywords

Farmers'

Perceptions,

Cassava,

Semi-Arid

Areas of Kenya

Article Info

Accepted:

23 January 2016

Available Online:

10 March 2016

Cassava is an important food security crop in the semi-arid areas of Eastern Kenya. Despite its importance during the long periods of drought and famine, no breeding programme has ever been conducted to improve the crop in Eastern Kenya. Therefore, this study was initiated by engaging farmers to identify researchable constraints that limit cassava production in the semi-arid areas. Participatory rural appraisal (PRA) tools, including two focus group discussions and interviews with 72 individual farmers, were conducted in Machakos, Kitui and Makueni counties in the eastern province of Kenya in 2004. Results from interviews revealed that farmers were growing 13 varieties, which were all late maturing (15 to $24 \mathrm{mo}$ ). The varieties were usually intercropped with other crops. Many farmers planted cassava after weeding the first planted grain crop, which exposed the crop to early season drought. Gender differences were apparent, as male farmers showed high preferences for varieties that produce long and thick round roots for the markets, while women preferred short and round roots that are easy to handle for domestic use, as well as for the local market. Both focus group and individual farmer interviews identified 11 production constraints that were perceived to be important. Farmers prioritised these constraints to the four most important ones, which in order of importance were drought, lack of suitable planting material, insect pests (green mites and mealy bugs) and disease (cassava mosaic). It was therefore agreed that breeding for early bulking varieties $(6$ to $10 \mathrm{mo}$ ) that escape late season drought was a priority. Breeding should also incorporate resistance to the important disease and pests. In addition, researchers should develop germplasm multiplication and dissemination methods for semi-arid areas.
\end{abstract}

\section{Introduction}

Cassava is an important food security crop in the semi-arid areas of Eastern Kenya. It provides food for a longer period in a calendar year than any other food crop grown in the region. Despite the importance of cassava in alleviating human suffering during the long periods of drought and famine, no breeding has ever been 
conducted to improve the crop in Eastern Kenya. For a long time farmers have depended on landraces and introduced germplasm, that often fail to meet their requirements. In order to devise a new and effective breeding programme there is a need to gather important information about farmers' perceptions of production constraints. Furthermore the breeder needs to know the local cassava preferences.

During the farming system research (FSR) approach, developed in the late 1970s and early 1980s, formal surveys were used to collect information from farmers. Surveys were laborious, time consuming and expensive to implement (Rifkin, 1992). They generated quantitative and or qualitative data, which was statistically analysed (Chambers, 1983). Nevertheless, these surveys did not easily allow for information outside the scope of the questionnaire to be collected. The researchers used the information to develop varieties without consulting target farmers in the process (Ashby et al., 1996). Subsistence farmers perceived research as an activity created to address the problems and needs of resource endowed large-scale farmers, who could influence government policy. Therefore, technologies that were developed at the time of FSR, were in many cases rejected by the subsistence farmers (Rukandema, 1983; Ockwellet al., 1988). In the current study a participatory approach, in which farmers are actively involved in generating information is followed as a way of accelerating adoption of new technologies.

A study conducted in the semi-arid areas of Kenya (Mavua, 1985) revealed that subsistence farmers reject new technologies for a number of reasons. The farmers complained that the new technologies required more fertilisers and agro-chemicals, which they could not afford. In semi-arid areas of Eastern Kenya, farmers rejected varieties selected from seed populations introduced from IITA on the basis of poor root qualities (Kamau et al., 1998b). In Uganda, Buaet al. (2000) reported that cassava varieties bred between 1990 and 1999 were abandoned immediately after release because they lacked in preferred enduser root qualities. Thus, new ways of ensuring cassava variety adoption have to be found. Breeding is perceived successful when target farmers adopt released varieties.

In an effort to improve on the passive and traditional methods of gathering information, the rapid rural appraisal (RRA) was developed in the late 1980s (Grandstaff, 1988; Conway, 1990). The RRA attempted to bring farmers' perspectives, practices and indigenous knowledge into the forefront of the planning process, improving on the traditional top-down development approaches. However, it failed to effectively articulate the interests of the rural farmers and adoption rate remained low (Paris and Atlin, 2005). In the late 1980s and early 1990s, the RRA was replaced by participatory rural appraisal (PRA), which emphasised active participation of farmers in the formulation of research objectives and selection process at an early stage in the breeding process (Chambers, 1993).

PRA was developed after it was realised that there was a need to analyse location specific problems. Researchers had to rely on the farmers' knowledge to understand the needs within each agro-ecology. PRA emphasised on the participation of both the researchers and producers in identifying the constraints and in technology development. It uses tools such as semi-structured interviewing, focus group discussions, preference ranking, mapping and modeling, seasonal and historical diagramming to identify and prioritize the production constraints time, and trend lines (Theis and Grady, 1991). 
PRA recognises the importance of farmers' indigenous knowledge and skills to understand the target area, identifies production constraints, and prepares the action plan together (Sperlinget al., 1993). Instead of the tedious questionnaire, PRA uses guiding questions to stimulate group discussion in semi-structured interviews. Open-ended questions or issues that arise during the discussion, are explored further during the interview (Theis and Grady, 1991; Chambers, 1993). The discussions are held in a friendly atmosphere, where everybody is perceived to be equal, irrespective of their status in society. It allows stakeholders to work together in identifying constraints, which are used to formulate research objectives (Sperlinget al., 1993). As a result, breeding has been made more participatory and opened the way for the concept of participatory plant breeding (PPB).

In PPB farmers and breeders make decisions together in the technology development. For example, if the subsistence farmers are not capable of buying inputs such as fertilizer and crop protection chemicals, varieties that are released should guarantee some acceptable yield level with minimum inputs (Okaliet al., 1994).

Examples of crop varieties that have been bred through PPB include grain legumes in India (Gupta, 1985), maize in Western Kenya (Odendoet al., 2002) and cassava in Brazil (Fukuda et al., 2000). Adoption rate of varieties developed through PPB is often good. In Tanzania, Kapingaet al. (1997) demonstrated that PPB accelerated dissemination and adoption of cassava technologies.

The main objectives of this study was initiated to work with cassava farmers in Eastern Kenya to identify researchable production constraints, prioritise them and develop cassava-breeding objectives for this semi-arid area.

\section{Materials and Methods}

\section{Study Area}

The eastern-mid altitude (800 to $1800 \mathrm{~m}$ ) and semi-arid areas cover two major agroecological zones in Kenya. One zone receives $700-800 \mathrm{~mm}$ of rainfall annually, classified as lower Midland zone 4 (LM4) and the second zone receives $500-600 \mathrm{~mm}$ of rainfall annually, classified as lower Midland zone 5 (LM5) (Jaetzold and Schmidt, 1983). From these zones two villages, namely Kathekakai in LM4, and Muuni village in LM5 in Machakos and Makuenicounties, were selected for the study. The local leaders and the extension staff of the respective districts selected the two villages on the day researchers visited the district offices of the Ministry of Agriculture. These two villages were selected for focus group discussions. Individual interviews were conducted in several divisions such as Central and Yatta in Machakoscounty, Makindu and Kasikeu in Makuenicounty, and KituiCentral in Kitui county.

\section{Machakos County}

In Yatta division, Matuu village was selected for individual interviews. Matuu village is along the Thika - Garisa road on the northeast side of Machakos LM5. Soils vary from red clay and loam soils to the heavy black cotton soils, which dominate the lower area. There is a canal that supplies water for irrigation and household use. Crops grown are mainly horticultural crops for export and local markets, and food crops such as tomatoes, kale, maize, beans, pigeon pea, pumpkins, cassava, sweet potatoes, bananas, mangoes and pawpaw. 


\section{Makueni County}

In district, Makindu and Kasikeu divisions were selected for the interviews. In Makindu division, Muuni village was chosen for the group and individual interviews, while Kasikeu village in Kasikeu division was selected for individual interviews only. Muuni village is located along the Nairobi Mombasa road, approximately $15 \mathrm{~km}$ south of KARI-Kiboko station in LM5. The soils are mainly sandy loam and red clay. Water comes from two wells, one borehole plus one line of piped water that is pumped once a week from the Kibweziriver, in the neighbouring division. The crops grown include maize, sorghum, millets, beans, and cowpeas, pigeon peas, green grams, cassava, sweet potato and cotton. Kasikeu village in Kasikeu division is about $10 \mathrm{~km}$ off Nairobi - Mombasa road, near Sultan Hamud. Soils are mainly sandy loam and the crops grown are maize, beans, cowpeas, pigeon pea, cassava, pumpkins and mangoes.

\section{Kitui County}

This district is mainly in LM5. Soils are sandy to sandy loam and farmers grow maize, sorghum, finger and pearl millets, cowpeas, mung beans, cassava and pumpkins The central division is divided into two by the Thika - Garisa road and was selected for the individual farmer's interviews only.

\section{Data Collection}

The research team comprised of the principal researcher (breeder), two socioeconomists, two technicians, one agricultural extension officer and a local leader. The local leader and extension staff assisted in moderating the discussions. The research team explained purpose of the research, the need of selecting study sites, the number of farmers required and a common understanding was created during team meetings prior to the PRA. During the meetings, the guiding questions and the role within each group were discussed, and lists of farmers and traders to be invited were finalised. The research team also gathered secondary data, on cassava production and utilisation, available from the local agriculture office. In each location the local extension officer and village leaders invited all the farmers by announcements at public places such as churches.

Facilitators used a guide questionnaire, probing further into any new information that arose from group discussions. The following PRA tools were used to collect data during group interviews (Figure 2. to 7): community sketch maps, time lines, trend lines and seasonal calendar (time allocation for different activities and by gender). Farmers were also requested to list all crops grown and institutions involved. A checklist of questions was used to gather data from community members. At some point, men and women were put in different sub-groups to come up with their own list of production constraints. This was necessary because in this region men are more concerned with cassava marketing, while ladies first consider the ease of handling during food preparation.

Individual farmers' interviews were conducted to obtainadditionaldata on crops grown, use of cassava as food and cash crop, cassava production constraints, types of cassava varieties grown, harvesting period after planting, preferred maturity period and common recipes.

\section{Results and Discussion}

\section{Focus Group Discussion}

At Kathekakai, 14 farmers $(58 \%$ men and $42 \%$ women) attended the meeting and 20 
attended at Muuni (42\% men and 58\% women). At Kathekakai, $38.9 \%$ of the group members had not received formal education, while $16.7 \%$ had been trained at various colleges. At Muuni, $19.4 \%$ had not received formal education, $50 \%$ attended first 8 y of primary education and $30.6 \%$ received college training.

Using time lines farmers at Kathekakai were able to describe their sub-location. Kathekakaiis a former large-scale beef and coffee farm. Local people formed a cooperative society to buy the farm in 1964. The new owners subdivided part of the land into 6 ha plots in 1965 to settle the shareholders, leaving the rest under beef and coffee. Cassava had been introduced on the farm, in the early twentieth century by the European settler to reduce food shortage among the farm workers. Two cassava varieties (Kikambaand Kiseliseli), were introduced by the Ministry of Agriculture in 1978. Farmers also grow maize, beans, pigeon pea and sweet potatoes in the village.

Before 1995, farmers replanted their own stakes or sourced them from neighbours and relatives. However, starting in 1995, $20 \%$ of the group members acknowledged buying stakes from the neighbouring, open day markets. Excess roots were sold in the local markets of Makaa, Mutituni and Machakos town.

The sub-location has no stockists for fertiliser chemicals and other farm inputs. Farmers buy from the neighbouring Mutituni market or Machakos town. However, the front line extension personnel from the Ministry of Agriculture provided technical advice to the farmers on crop and animal husbandry.

Muuni sub-location is a recent settlement scheme, created by the government of
Kenya in 1995 to settle the landless. In the first $5 \mathrm{y}$ of settlement, cassava cultivation expanded more than any other crop. Additional planting materials came from the neighbouring villages in Makindu and Kibwezi divisions. The farmers experienced heavy cassava losses from the wild animals, in particular baboons, pigs, porcupines and elephants from Tsavo West National Park. To curb the wild animal menace the farmers subdivided their farms and sold to other people who cleared the bushes where the animals were hiding.

Important trend lines on cassava production were analysed using the farmers' perception of availability of adequate rains, occurrence of cassava diseases, pest incidences and root yields in the two sub-locations. The two focus groups agreed that the years 1974, 1984, 1989, 1994 and 1999 to 2005 were characterised by serious food shortage and famine. Cassava cultivation was affected by lack of rainfall and lack of planting materials. Heavy rains, characterised by flooding, were reported in 1966, 1997 and 1998 and cassava in the valleys was destroyed by water. Other years had near normal-rainfall (400 to $800 \mathrm{~mm}$ ) and farmers had enough cassava for domestic use and surplus for sale. However, farmers from the two villages thought annual rainfall has been declining since 1960s for reasons they could not explain.

From 1987, farmers in Kathekakai started observing deformed leaves and some stems turning white on some cassava plants. The group at Muuni had seen such symptoms at their original homes, but were not aware that it was a problem. Both groups reported that the plants with deformed leaves sometimes gave low yields.

Each group listedvarieties they grew and the number of months it took to harvest. 
Varieties supplied by the Ministry of Agriculture were considered improved (Table 5). These varieties, such as Kibandameno, Binti Athumani and Kalesho, were farmers' introductions from the coast, while Mucericeri had been released from KARI-Katumani in the late 1970s.

The PRA exercise was conducted in 2004, a period when the region was experiencing severe drought conditions. All the cassava in the fields had been harvested. The few plants left on the farm had lost all their leaves and all the tubers harvested. As a result, it was not possible to differentiate improved from local varieties. Men could not clearly differentiate the varieties, but women were able to describe each variety (Table 5).

Both groups acknowledged that the improved varieties were introduced by the Ministry of Agriculture (MOA) and nongovernment organisations (NGOs). Group members at Kathekakai obtained extra planting materials from the neighbouring Mutituni location, while at Muuni farmers obtain stakes from neighbouring villages in Kibwezi division. On average most $(60 \%)$ of the planting materials were exchanged with neighbours and relatives (Figure 8).

About $40 \%$ of the group members intercrop cassava with maize. The cassava is planted after the first maize weeding. However, 35\% of the farmers plant cassava as a sole crop at the onset of the rains (Figure 9).

A list of farmers' preferences for an improved variety was made by the two focus groups (Table 6). The list was similar for both groups except that farmers from Muuni wanted a variety that can grow up to $2 \mathrm{~m}$ tall. At Kathekakai, plant height was important because cassava generally grows tall, but at Muuni, cassava rarely grows more than $1 \mathrm{~m}$. Both men and women from the two villages agreed on most of the attributes. However, men would like a variety that produces long and thick round roots for marketing, while women preferred short and round roots that are easy to handle for domestic use (Table 6).

Farmers valued the long period that cassava roots are available in a year (Table 7). Furthermore, they mentioned the many dishes that can be prepared from cassava and its role as a food security crop and a cash crop (Table 8).

Each focus group listed all the crops they grew in their respective areas. The members considered the amount of food harvested per unit land and which food crop is available during the drought periods. By a show of hands the crops were ranked in the order of their importance as food security and cash crop. Cassava took the first position as the most important food security crop (Table 9). Farmers also considered the advantage of being able to sell cassava quickly in case of need. Maize and beans were ranked higher because they store well, while cassava was placed in fourth and fifth position as a cash crop at Kathekakai and Muuni, respectively (Table 9).

The two focus groups identified and ranked the following constraints that limit cassava production in the semi-arid areas: poor soil fertility, drought, inappropriate varieties, inadequate planting materials, diseases and pests (termites, stem scales, white flies, wild animals and thieves). In addition, there were lack of well-defined markets, inadequate knowledge about cassava husbandry and processing of cassava. Ranking was done by the gender subgroups in each village. The ranking by the men and women of the constraints differed (Table 10). Women from the two sub-locations indicated that 
appropriate knowledge on cassava production and technologies were essential in promoting production. Drought was ranked the number one constraint at both Kathekakai and Muuni (Table 10).

Using their own understanding of the constraints, the focus groups listed a number of solutions to each of the first four constraints they considered most important (Table 11).

\section{Individual Farmer Interview}

A total of 72 households from Machakos, Makueni and Mwingi districts were visited. In each farm, the head of a household or a representative was interviewed of whom $21 \%$ respondents were women. About $55 \%$ of the household heads had attained different levels of the first $8 \mathrm{y}$ of primary education, $19.4 \%$ high school (16 y of schooling) and $5 \%$ college education (Figure 10). Most of the heads of household (87.3\%) lived and worked on their farms and only $12.7 \%$ had formal employment. However, $82 \%$ of them depended on their farm produce for the family food and income (Figure 11).

Out of the 72 individual farmers interviewed, $77.8 \%$ intercropped cassava with food crops such as maize, grain legumes (beans, cowpeas, pigeon peas, dolichos, mung beans), sorghum and millets, sweet potato, vegetables, sugar cane and fruits (mangoes, guavas and pawpaw). Only $8.3 \%$ planted it as sole crop (Figure 12).

The individual farmers listed 13 varieties, which they grew. Farmers considered varieties, brought in by the Ministry of Agriculture and non-governmental organisations, as improved. The two varieties, Mucericeri and Yangaitune were considered early (Table 12)

A total of $65 \%$ farmers were willing to adopt early bulking varieties with preferred root qualities and abandon the traditional varieties (Figure 13). The remaining group $34.7 \%$ would adopt and keep their traditional varieties. A majority $(75 \%)$ of the farmers indicated that they would like a variety that can be harvested at between 6 and 10 mo after planting (Figure 13).

According to the individual interviews, majority of the farmers $(66.8 \%)$ planted cassava during the short rains season. It is only the few farmers in Yatta division of Machakos district, who have furrow irrigation, who planted during the long rains (Figure 14). Planting was done after the rains had started by mature women in the family, while all family members did weeding.

When the individual farmers were asked about the importance of cassava, $91.7 \%$ said that it was the most important food security crop. Fifty eight percent of the respondents thought that cassava was an important cash crop (Figure 15).

The following constraints were identified; drought, planting materials, diseases and pests. Over $55 \%$ of farmers thought drought was the most serous constraint that research should address, followed by planting materials, diseases and pests (Figure 16).

According to $51.4 \%$ of the farmers the solution for drought was to breed for early bulking varieties, while $5.6 \%$ of the farmers mentioned irrigation (Table 13). The interview showed that $16 \%$ of the farmers would be willing to buy planting material, while $4 \%$ said they should be trained in methods of conserving planting material. About $9 \%$ of the individual farmers thought they could control pests by spraying with chemicals and diseases by uprooting the sick plants (Table 13). 
Table.1 Description of Cassava Varieties by Women Groups in Kathekakai and Muuni Villages

\begin{tabular}{lll}
\hline Variety & Kathekakai & Muuni \\
\hline Kitwa (local) & -2 m tall & -high branching \\
& -scaly roots, red outer skin & -red outer skin colour \\
& -cracks when mature & -high dry matter, easy to peel \\
Mucericeri & -late maturing $(18 \mathrm{mo})$ & -late bulking $18 \mathrm{mo}$ \\
(improved) & -white outer skin & -short roots $(300 \mathrm{~mm})$ \\
& -short roots $(300 \mathrm{~mm})$ & -white outer skin \\
& -early maturing $(15 \mathrm{mo})$ & -early bulking $(15 \mathrm{mo})$ \\
Kisimba (local) & -low dry matter, bitter at times & -low dry matter, bitter at times \\
& -2 m tall & $-2 \mathrm{~m}$ \\
& -white flesh, red outer skin & - \\
& -cracking when mature & \\
Kiou (local) & -late maturing $(18 \mathrm{mo})$ & \\
& -1 m tall & -low branching \\
& - & -early bulking \\
& & -red outer skin colour \\
& & -easy to peel \\
\hline
\end{tabular}

Table. 2 Cassava Variety Characteristics Preferred by Farmers in Kathekakai and Muuni Villages

\begin{tabular}{lll}
\hline Characteristics & Kathekakai & Muuni \\
\hline Plant height & Tall (but not important) & Medium (1.5 to 2 m) \\
Root shape & Long, straight and round & Elliptic (no constrictions) \\
Size & Long (men) and short (women) & Long (men) and short (women) \\
Flesh colour & White & White \\
Texture & High dry matter & High dry matter \\
Taste (when raw) & Sweet & Sweet \\
Maturity period & Early (preferably $<10 \mathrm{mo})$ & Early (preferably $<10 \mathrm{mo})$ \\
\hline
\end{tabular}

Figure.1 Organisations that have Provided Planting Materials Before

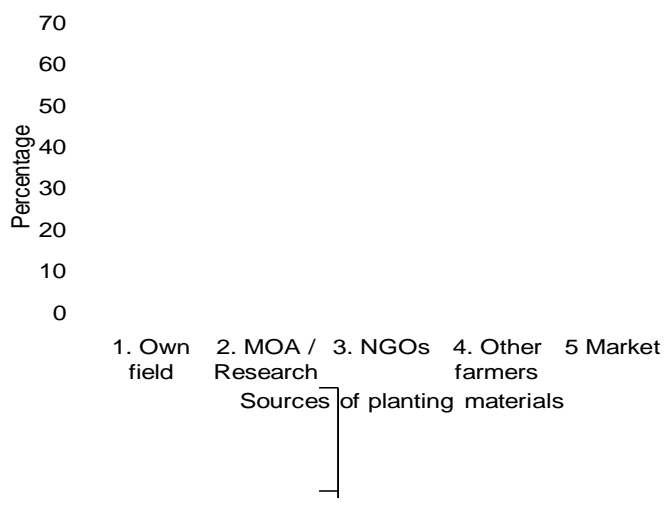


Table.3 Period for which each Crop was Important for Household Food Security in Kathekakai and Muunivillages

\begin{tabular}{lll}
\hline Crops & Kathekakai & Muuni \\
\hline Cassava & August - February & April - December \\
Cowpea & December - January; February and June & December - January; February \\
Beans & January - February and June & January \\
Dolicos & N/A & May to June \\
Green gram & N/A & January \\
Maize & February \& July & February \\
Sorghum & February & April \\
Avocado & February - December & N/A \\
Bananas & Throughout the year & N/A \\
Garden pea & April & N/A \\
Pigeon pea & June - August & June - August \\
Broad bean & May - June & N/A \\
Pumpkin & June & June \\
Sweet potato & April and August & February and August \\
Finger millet & N/A & March \\
\hline N/A Not applicable & &
\end{tabular}

Table.4 Common Dishes Prepared from Cassava

\begin{tabular}{lll}
\hline Tubers & Dish & Preparation after peeling \\
\hline Fresh roots & Snack & The sweet roots peeled and chewed raw \\
Cooked fresh roots & Kisili & Roots chopped, fried with, meat or legumes \\
& Kitau/ Mukimwa & Roots boiled with maize, bean and mashed. \\
& Milikyo & Cassava roots chopped and boiled alone \\
Processed products & Munyoloka - uvesi & Cassava flour used to prepare ugali \\
& Chapati & Boiled cassava or flour mixed with wheat flour \\
& Mwanga & Composite cassava-maize flour to cook ugali \\
& Porridge & Composite cassava-maize/ millet/ sorghum flour \\
Leaves & Vegetables & Young leaves are pounded washed and fried \\
\hline
\end{tabular}

Figure.2 The Time of Introducing Cassava in the Cropping Season

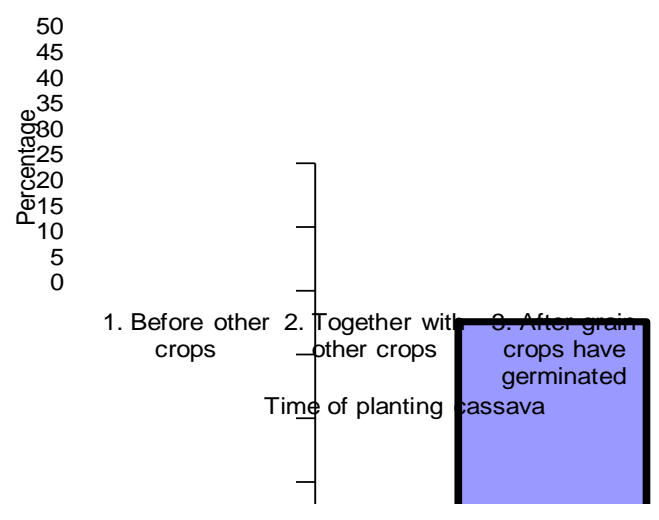


Table.5 Ranking of Crops Grown for Food Security or Cash Crop in Kathekakai and Muuni Villages

\begin{tabular}{lcccccccc}
\hline Crops & \multicolumn{4}{c}{ Kathekakai } & \multicolumn{5}{c}{ Muuni } \\
& \multicolumn{1}{c}{ Food security crop } & \multicolumn{2}{c}{ Cash crop } & \multicolumn{2}{c}{ Food security crop } & \multicolumn{2}{c}{ Cash crop $^{\text {Cank }}$} \\
\cline { 2 - 9 } & Score $^{+}$ & Rank & Score $^{+}$ & Rank & Score $^{+}$ & Rank $^{\text {Score }}$ & Rank \\
\hline Cassava & 8 & 1 & 4 & 4 & 7 & 1 & 4 & 5 \\
Maize & 6 & 3 & 8 & 1 & 3 & 6 & 8 & 1 \\
Beans & 5 & 4 & 7 & 2 & - & 9 & 7 & 2 \\
Sweetpotato & 7 & 2 & 4 & 5 & 5 & 5 & 3 & 6 \\
Cowpea & 4 & 5 & 4 & 6 & 6 & 2 & 1 & 9 \\
Pigeon pea & 3 & 6 & 6 & 3 & - & - & - & - \\
Sorghum & 2 & 7 & 2 & 7 & 5 & 3 & 1 & 8 \\
Pearl millet & - & & - & & - & - & - & - \\
Finger millet & 1 & 8 & 1 & 8 & 2 & 7 & 6 & 3 \\
Dolicos & - & - & - & - & 2 & 8 & 2 & 7 \\
Green gram & - & - & - & - & 5 & 4 & 5 & 4 \\
\hline
\end{tabular}

Table.6 Ranking of Constraints by Gender atKathekakai and Muuni Villages

\begin{tabular}{|c|c|c|c|c|c|c|c|c|}
\hline \multirow{3}{*}{ Constraints } & \multicolumn{4}{|c|}{ Kathekakai } & \multicolumn{4}{|c|}{ Muuni } \\
\hline & Women & & Men & & Women & & Men & \\
\hline & Score $^{+}$ & Rank & Score $^{+}$ & Rank & Score $^{+}$ & Rank & Score $^{+}$ & Rank \\
\hline Poor soil & 1 & 8 & 3 & 3 & & & & \\
\hline Drought & 5 & 4 & 5 & 1 & 5 & 1 & 6 & 1 \\
\hline Planting materials & & & & & 4 & 2 & 5 & 2 \\
\hline Disease & 4 & 5 & 4 & 2 & & & 3 & 4 \\
\hline Pest & 3 & 6 & 2 & 4 & 3 & 4 & 4 & 3 \\
\hline Livestock & & & & & 2 & 5 & & \\
\hline Market & 7 & 2 & & & & & & \\
\hline Wild animals & 2 & 7 & & & & & & \\
\hline Theft & & & & & & & & \\
\hline Appropriate varieties & 6 & 3 & 1 & 5 & & & & \\
\hline $\begin{array}{l}\text { Inadequate knowledge of } \\
\text { cassava production }\end{array}$ & 8 & 1 & & & 4 & 3 & 1 & 5 \\
\hline
\end{tabular}

Table.7 Possible Solutions to Constraints Identified at Kathekakai and Muuni Villages

\begin{tabular}{|c|c|}
\hline Constraints & Possible solutions \\
\hline Drought & $\begin{array}{l}\text {-early maturing varieties or drought tolerant/ resistant varieties, } \\
\text { - mulching, water harvesting and irrigation }\end{array}$ \\
\hline Planting materials & $\begin{array}{l}\text {-establish appropriate multiplication and supply channels } \\
\text {-preservation in trenches, under shade and hanging in trees }\end{array}$ \\
\hline Disease $(\mathrm{CMD})^{\dagger}$ & -uproot affected plants and use of resistant varieties \\
\hline $\begin{array}{l}\text { Pests (white flies, stem } \\
\text { scales, mites, termites, } \\
\text { thieves and wild } \\
\text { animals) }\end{array}$ & $\begin{array}{l}\text {-training on the use of chemical control, trapping and scaring } \\
\text { - use of repellents (burn animal dung), relocate wild animals to national parks } \\
\text { or seek spiritual interventions for the thieves }\end{array}$ \\
\hline
\end{tabular}


Table.8 List of Cassava Varieties Grown in the Semi-arid aAreas (I=Improved; L=Local)

\begin{tabular}{lc}
\hline Variety & First harvesting (months after planting) \\
\hline Mucericeri (i) & 15 \\
Yangaitune (L) & 15 \\
Kitwa (L) & 19 \\
Yangayeu (L) & 20 \\
Kibandameno (L) & 19 \\
Bintiathumani (L) & 20 \\
Kaleso (L) & 19 \\
Kikamba (L) & 20 \\
KME 1 (I) & 19 \\
KME 61 (I) & 24 \\
Kisui (L) & 21 \\
Mbili (L) & 24 \\
Mpira (L) & 24 \\
\hline
\end{tabular}

Table.9 Solutions to the Constraints Identified from Individual Interviews

\begin{tabular}{llc}
\hline Constraints & Solutions & Percent of farmers \\
\hline Drought & Early maturing varieties & 51.40 \\
Drought & Irrigation & 5.60 \\
Planting material & Train in conservation & 4.20 \\
Planting material & Be advised the place to buy & 16.70 \\
Pests & Pesticide & 9.70 \\
Disease & Uproot or resistant varieties & 8.30 \\
All above & Do not know & 4.20 \\
\hline
\end{tabular}

Figure.3Education Levels of Heads of Households

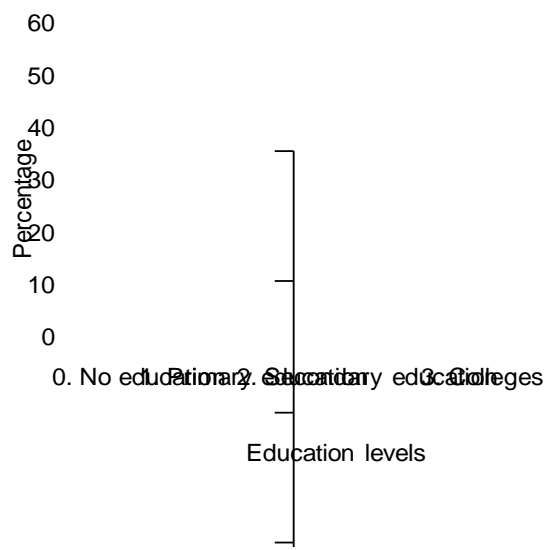


Figure.4 Characteristics of the Head of the Households

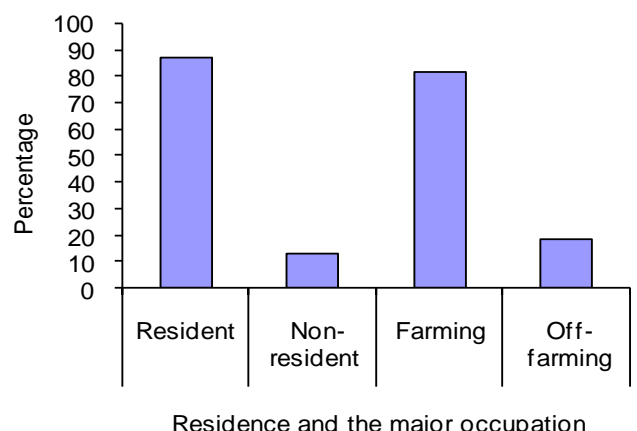

Figure.5 Cropping Systems for Cassava

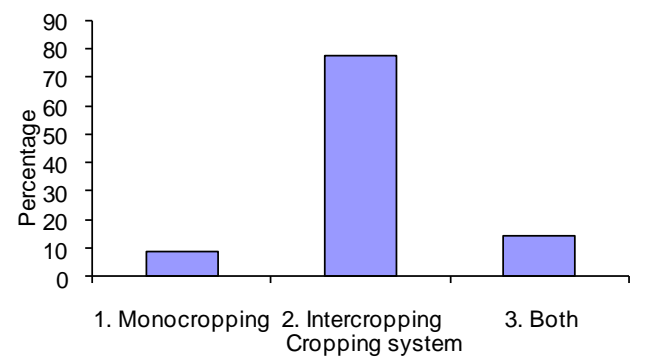

Figure.6 Farmers Preferences on the Period of an Early Bulking Variety

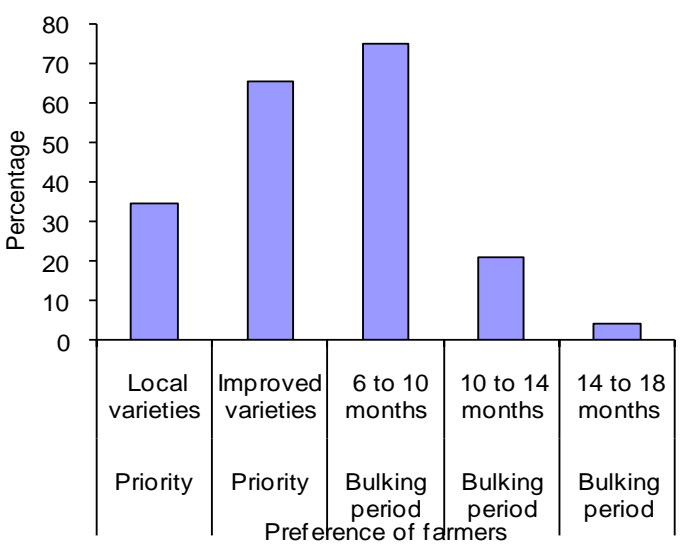


Figure.7 Season Farmers Prefer to Plant Cassava

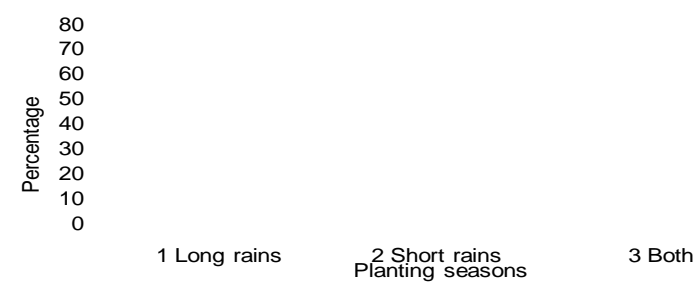

Figure.8 Percentage of Farmers Growing Cassava as Food and Cash Crop

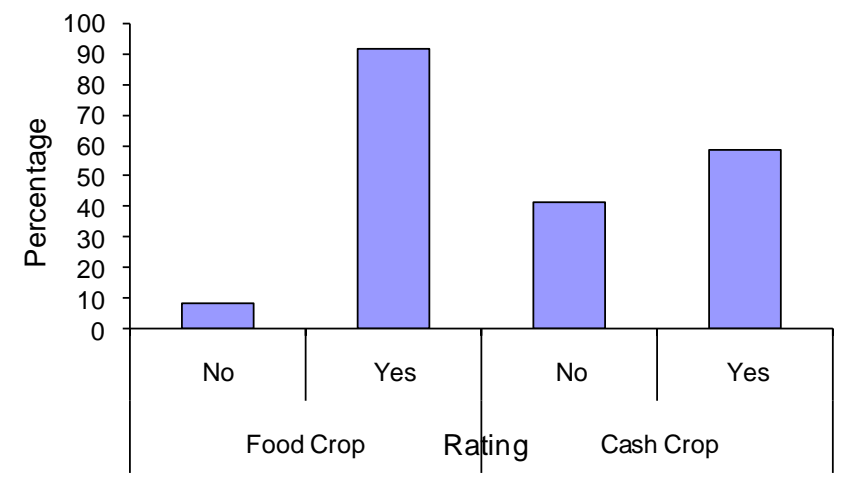

Figure.9 Cassava Constraints Identified by Individual Interviews

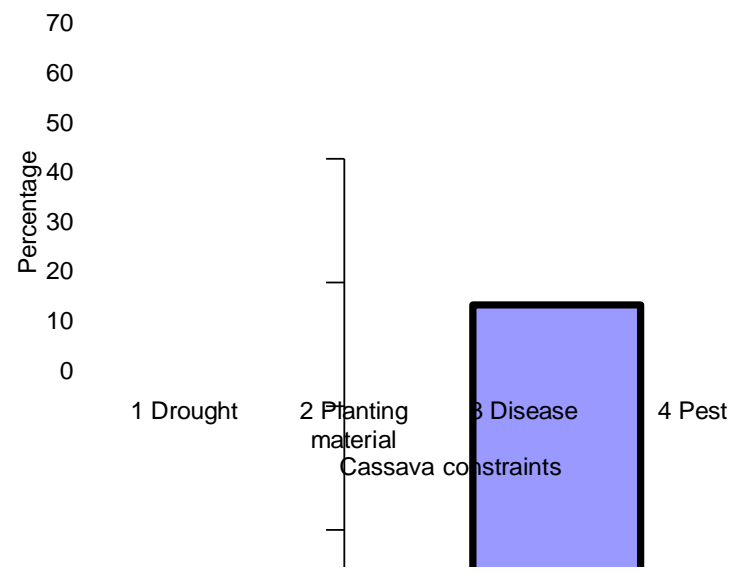


In conclusion, the aim of this study was to involve cassava producers in identifying cassava production constraints and preferences. Farmers proved to have detailed insights into the cassava production system and they were willing to share information freely with the research team. The combination of focus group and individual interviews resulted in a detailed picture of all the aspects of cassava production. The farmers responded particularly well to focus group discussions and the whole group openly and freely discussed ideas initiated by one person. The open-ended nature of the questions generated answers that would not have been obtained from the individual interviews. Separating males and females proved beneficial at times.

Trend lines were important tools to study how cassava production has taken its place in the local economy over time. Farmers remembered events going back to the year they settled in their villages. Members of the focus groups were able to recall easily the years the villages had received above normal rainfall, characterized by flooding, and years with below normal rainfall. In the last decade farmers have observed an increase in plants with what appear to be diseased leaves. Farmers were aware that rainfall in the region was unreliable, inadequate and has been declining over the years. The general perception was that area under cassava production has increased in recent years.

The farmers emphasised the importance of cassava as a food security crop in the semiarid area. They knew that cassava out-yields all other crops grown and it is the only crop available during the long dry period from June to November. Therefore, cassava is a very important crop, especially to children, women and the aged who suffer malnutrition and become vulnerable to diseases during the drought and famine periods. Apart from food, the crop proved important as source of income to the families. Cassava serves as a cash crop and provides employment to many, young and old.

Gender differences were obvious when the focus groups were subdivided into men and women subgroups. It emerged that the men are more concerned with marketing of cassava and require varieties that produce long and thick roots. Women would like varieties that produce short thick roots that are easy to carry in a basket or handle when preparing meals. The ladies were more concerned with family food and only considered selling on the market when there was excess.

Over the years farmers appear to have proactively introduced cassava from other areas, mainly from the coastal region. They were aware of the differences between varieties in bulking period, and knew advantages and disadvantages of each variety. Most varieties were late bulking. Gender differences were evident, when men could not clearly describe all the varieties grown, while women were very knowledgeable about differences between varieties. The farmers were keen to adopt new improved varieties, as long as they combined preferred root qualities with early bulking.

Pairwise ranking proved an important tool to facilitate the ranking of cassava production constraints by the farmers. The women wanted to be trained on the crop's husbandry and processing while men thought diseases and pests were important. The groups agreed that research should address drought first, followed by unavailability of planting materials. Development of early bulking varieties should also include resistance breeding to pests and diseases important in the areas. The farmers emphasised the need for 
varieties that would escape the long drought period of June to November. Discussion of the seasonal calendar was used to find out when cassava is planted and introduced in the cropping system.

Farmers had strong views of the kind of variety they prefer. The varieties should be early, with sweet (low HCN), high dry matter and short, thick roots. Farmers in agro-ecological zone LM5 wanted tall varieties, to give them more planting material.

The PRA has highlighted the importance of cassava in the farming system of the semiarid areas of Kenya. Constraints have been prioritised and the need for early bulking varieties, with resistance to important pests and diseases, established. Men and women had at times differing views of the ideal cassava plant. The farmers have demonstrated the willingness to work together with the researchers in solving the production constraints that affect cassava in the area. In order to develop appropriate varieties, which have the preferred end-user root and plant habit qualities, participatory plant breeding will need to be an integral part of the cassava breeding programme for the semi-arid areas of Kenya.

\section{References}

Ashby, J., Quiros, C. and Rivers, Y., 1996. Farmer Participation in Technology Development Work with Crop Varieties. Farmer First Intermediate Technology Publications. London. $115-122$.

Bua, A., Acola, G., Adupa, R.L., OtimNape, G.W., Baguma, Y.K. and Ssemakula, D.,

2000. Adoption and Impact of Improved Cassava Varieties in Ugandahttp:// ecart.iao.florence.it/Documents/Cass ava Varieties 95.doc, $15^{\text {th }}$ August,
2003.

Chambers, R. 1983. Rural Development: Putting the Last First. Burnt Mill, Hallow, Essex: Longman. 252.

Chambers, R. 1993. Challenging the Professions: Frontiers for Rural Development.

London: Intermediate Technology Publications.

Conway, G. 1990. After the Green Revolution: Sustainable Agriculture for Development. Earthscan, London, 1990.

Fukuda, W.M.G., Fukuda, C. and Saad, N. 2000. Scaling up of participatory cassava

breeding in Brazil: A case study from Northeast Brazil.

Grandstaff, S. 1988. Bibliography on rapid rural appraisal. In: Proceedings of the 1985International Conference on $R R A$. Rural System Research and Farming Systems Project,KhonKaen University, KhonKaen, Thailand.

Gupta, A.K. 1985. Sustainable institutions for natural resource management: How do we participate in people's plans? In: Samad, S.A. Watanabe, T. andSeung-Jin Kim (eds). People's Initiatives for Sustainable Development: Lessons of Experience. Published by APDC. pp. $341-373$.

Jaetzold, R. and Schmidt, H. 1983. Farm Management Handbook of Kenya. Volume 4. Nairobi, Kenya Ministry of Agriculture.

Kamau, J.W., Kinama, J.M., Nguluu, S.N., Muhammad, L., Whyte, J.B.A., Ragwa, S.M.,

Migwa, E.N., and Simiyu, P.M. 1998. Farmer's evaluation of cassava varieties in semi-arid areas of Kenya. In: Akoroda, M.O., and Ngeve, J.M. (eds.) Root Crops in the 21st Century. Proceedings of the 7th 
Triennial Symposium of the International Society for Tropical Root Crops-AB. pp. 378 - 383

Kapinga, R., de Steenhuijsen, P.B., Kajiru, S., Chirimi, J., Rugutu, C. and Mahungu, N.M. 1997. Selection of cassava varieties by farmers in the lake zone of Tanzania. African Journal of Root \& Tuber Crops 2: $248-253$.

Mavua, J.K. 1985. Research - Extension Farmer Linkages: The approach and experience of Katumani, Kenya. MSc. Thesis, University of East Anglia-Norwich, England.

Ockwell, A.P., Muhammed, L. and Nguluu, S. 1988. Farming systems of semi-arid areas of Eastern Kenya: A case study of 18 Farms. Australian Centre for International Agricultural Research (ACIAR). Goanna Print Pty Ltd: Canberra, Australia.

Odendo, M., De Groote, H., Odongo, O.and Oucho, P., 2002. PRA of farmers' criteria for selection of maize varieties and constraints to maize production in the moist mid- altitude zone of Western Kenya: a case study of Butere-Mumias, Busia and Homa Bay Districts. Final Technical Report. March 2002.

Okali, C. Sumberg, J. and Farrington, J., 1994. Farmer participatory research: Rhetoric and reality.
Intermediate Publications, London.

Technology

Paris, T. and Atlin, G., 2005. Current participatory breeding projects conducted by the centres represented at the workshop. Farmers and scientists building a partnership for proving rain-fed rice in the Eastern India-Phase.

Rifkin, S. 1992. Rapid appraisals for health: An overview. Rapid Rural Appraisal Notes Number 16. Special Issue on Applications for Health, July 1992.

Rukandema, M. 1983. Farming systems of semi-arid Eastern Kenya: A comparison. Special issue of the East African Agricultural and Forestry Journal 44.

Sperling, L., Loevinsohn M. and Ntabomvura, B. 1993. Rethinking the farmer's role in plant breeding: Local bean experts and on-situation selection in Rwanda. Experimental Agriculture 29: 509-515.

Theis, J., and Grady, H. 1991. Participatory Rapid Appraisal for Community Development: a Training Manual Based on Experiences in the Middle East and North Africa. Save the Children and IIED, London.

\section{How to cite this article:}

Mohammad Joseph Kamau, Rob Melis, Mark Laing, Paul Shanahan, Jon Derera, Kahiu Ngugi and Yusuf Migwa. 2016. Farmers' Perceptions of Production Constraints and Preferences in Cassava Grown in Semi-Arid Areas of Kenya. Int.J.Curr.Microbiol.App.Sci.5(3): 844-859. doi: http://dx.doi.org/10.20546/ijcmas.2016.503.098 